\title{
ANDRIJA ŠTAMPAR AND THE INSTITUTE FOR MEDICAL RESEARCH AND OCCUPATIONAL HEALTH ${ }^{*}$
}

\author{
Marko ŠARIĆ \\ Institute for Medical Research and Occupational Health, Zagreb, Croatia \\ Received in June 2008 \\ Accepted in November 2008
}

The year 2008 has seen a double jubilee of two important and related events. The first is the $120^{\text {th }}$ anniversary of Andrija Štampar's birth, which coincides with the $50^{\text {th }}$ anniversary of his death. The second jubilee is the $60^{\text {th }}$ anniversary of the Institute for Medical Research and Occupational Health, established by the Assembly of the Yugoslav Academy of Arts and Sciences on 27 December 1947 as Institute for Industrial Hygiene, upon the initiative of Andrija Štampar, who then presided over the Academy.

Croatian Academy of Sciences and Arts and the Institute for Medical Research and Occupational Health celebrated the occasion with a scientific symposium entitled "Current Research in Occupational and Environmental Health" held on 28 November 2008.

The year 2008 has seen a number of memorial conventions on Štampar's life and work, most of which focused on his role in the advancement of health care at home and at the international level. I will limit this brief review on Štampar's role in the advancement of science, paying particular attention to the foundation of what is now the Institute for Medical Research and Occupational Health. Before I do that, however, I would like to take a short look at Štampar's eventful life (1).

Andrija Štampar was born in Drenovac, a village near Slavonski Brod, on 1 September 1888. He completed secondary school in Vinkovci, and graduated from the Vienna School of Medicine in 1911. As early as his student days he was interested

* Translated from Croatian by Dado Čakalo in bringing knowledge about health to the people. He would print handbooks with practical advice and write educational articles on how to fight tuberculosis, alcoholism, and acute infectious diseases. He championed socially sensitive medicine and strong public health, and remained true to these early ideals for the rest of his life.

At the turn of 1912, Stampar found himself at the position of ward physician in the town hospital of Karlovac and then as a district physician of Nova Gradiška. He continued to publish educational and health articles. In some he severely criticised current healthcare services in Croatia and called for social reform. In 1916, he was drafted to serve as a military physician of an infantry regiment in Sisak, but was soon relocated to Mauthausen prisoner-of-war camp as a political maverick until the fall of the Austrian Empire. In November 1918, he was asked by the People's Assembly in Zagreb to take the position of healthcare advisor for the Welfare Committee. His views, activities, and zest have won him the sympathies of an eminent hygienist and organiser of healthcare services Milan Jovanović Batut, professor at the Belgrade School of Medicine. Batut invited Stampar to take over the Department of Hygiene of the Ministry of Public Health of the newly constituted kingdom of Slovenes, Croats, and Serbs. Over the ten years at this duty, Štampar established a national healthcare service based on his ideological tenets, started or approved over 250 public health and hygiene institutions, launched a number of bills and 
regulations, and endorsed specialist training for a great number of physicians in a variety of medical fields. His attempts to bring healthcare services of physicians and pharmacists closer to people was fiercely opposed by the respective guilds.

For all that, Stampar's efforts and accomplishments were met with highest acclaim by international health organisations and institutions. Štampar's influence accounts for substantial financial and technical support received from the League of Nation's Health Organization and Rockefeller Foundation for the development of our healthcare system. This includes the School of Public Health established in Zagreb in 1927. While Štampar was in office, Rockefeller Foundation financed the completion of the Institute of Hygiene in Belgrade.

Štampar's work at the Ministry of Public Health was stopped short by king Alexander declaring dictatorship on 6 January 1929. He was moved to the position of the chief inspector for hygiene and retired in 1931.

This is when the Council of the Zagreb School of Medicine elected Štampar full professor of hygiene and social medicine, but his tenure was not endorsed by the authorities, and Štampar decided to go abroad. At first he worked for the Health Organization of the League of Nations, and helped Chinese authorities organise their public health.

In spring 1939, his tenure at the Zagreb School of Medicine was finally endorsed, and in the same year he published a book Zdravlje $i$ društvo (Health and Society) bringing his observations and experiences from many countries he visited all over the world. $\mathrm{He}$ also prepared a textbook on hygiene and social medicine for medical students in 1940. World War 2 halted his activities, most of which were focused on the improvement of medicine teaching at the time. Štampar was arrested by German police and taken to Graz, where he saw the end of the war as intern. In May 1945 he returned to Zagreb and to teaching hygiene and social medicine. He also became a director of the School of Public Health that, under his office, became part of Zagreb University School of Medicine.

In the school year 1945/46, Štampar became the chancellor of Zagreb University and was also elected dean of the School of Medicine on several occasions. As dean, he started a number of important school reforms, focusing on preventive and social aspects and on extending student practice to non-university hospitals. It was his merit that the High Nursing School in Zagreb and the School of Medicine in Rijeka saw the light of day.

As the Yugoslav Academy of Arts and Sciences reorganised and resumed activity in 1947, Štampar became its full member and president.

In the early postwar years Štampar worked hard to restore international cooperation. At the 1946 United Nations conference in London he was elected the first vice-president of the Economic and Social Council, and was appointed to the Technical Preparatory Committee for constituting what would become the World Health Organization (WHO). In 1946, he was elected chair of the Interim Commission to manage the functions of the WHO in New York until its constitution was formally ratified on 7 April 1948 . $\mathrm{He}$ presided over the inaugural Assembly meeting in Geneva in June 1948. At the Eighth World Health Assembly meeting in Mexico in May 1955, he received the Léon Bernard Foundation Prize - the most eminent international award in social medicine.

Now, resuming my inquiry about Štampar's relation to science, it would be interesting to see what made him initiate setting up the Institute for Industrial Hygiene, which now celebrates its $60^{\text {th }}$ anniversary under the current name Institute for Medical Research and Occupational Health.

A few excerpts from Stampar's speech held at Academy's inaugural assembly of 28 December 1947 (2) may give an idea about his motives:

Over the last five or six centuries, the Croatian people has seen a shining phalanx of outstanding personalities, thinkers, poets, ideologists, and politicians, who all shared a dream of freedom and pursued the ideal of national unity and liberation. Eighty years ago, our Academy developed a programme that rested on this rich ideological tradition. Under unhealthy political conditions and constant threats by conservative, ultra-reactionary foreign authority, the Academy was limited to linguistic and medieval studies. This is why 25\% of all Academy's works are on language studies, $33 \%$ on history, $10 \%$ on natural sciences, and less than 1\% on economy and social sciences. These relations between disciplines cherished by the Academy speak about the political polarisation of our science along the line of least resistance and about the growing escapism into spiritual realms from the harsh economic and political realities of life over the last fifty years of Austrian rule.

Stampar then continues as follows:

The position of science in society is much different today from where it stood before, and especially in the 
$19^{\text {th }}$ century, when it was developed by individuals, without a particular plan, and often in the service of private interests. Today, science has taken over an important social role and has been serving mankind as a whole. It starts from the needs of man, for science can teach how to meet these needs. The basic human needs are physiological and social. Physiological priorities are food, shelter, health, and rest. Then follow the means to meet these needs such as products industry, transport, and administrative, economic, and political organisation.

[...]

Work is one of the major human needs. But work should be joy, not slavery. Science can help the worker to harness the machine, and not the other way around.

Stampar continues to unfold his simply put and clear views by stressing that the Academy "[...] has already started establishing new institutes and reviving or expanding the old ones". Štampar insists on organised approach to science, and announces the establishment of an institute for the Adriatic studies, institute of the karst, institute of economy, institute of parasitology, food institute, and institute of industrial hygiene (occupational health). Speaking of the last, Štampar says that "[...] this Institute will study the physiology and pathology of work. This research will coincide with the galloping industrialisation of the country, which calls for resolving a number of arising issues related to industrial hygiene".

Štampar's view of the role of science in modern life, and of the need to orchestrate scientific research - at the time when there was no such tradition to draw on or resources at hand - is perhaps best illustrated by the following paragraph from a report issued by the Academy's secretary general Branimir Gušić for the first regular assembly in 1950 (3). Section III: Institute's Setup reads as follows:

I would particularly like to distinguish the merits of academician Štampar not only in establishing the Institute for Industrial Hygiene (Occupational Health), but also in establishing other basic science institutes. Thanks to his dedication, the people's government has planned a large area of land for their construction, starting with this year's (1950) investment plan for the Institute of Experimental Biology.

This land later saw the construction of the Ruđer Bošković Institute and Institute of Physics. This is also where the Zagreb University Faculty of Science has finally found home in new buildings.
Speaking of the need to establish the Institute for Industrial Hygiene (Occupational Health), Štampar said that " $[. .$.$] we need to be aware that workers'$ health is not only a humanitarian issue, but the pre-requisite of the successful development of our socialist economy." Štampar would stress that the only successful way to address workers' health issues was the scientific way (4). Guided by these tenets, the newly found research institute defined the scope of its activities, as follows: 1) research and study of physical and biotic conditions at work and study of industrial hygiene (occupational health), especially in domestic economy and industry; 2) providing access to research results to the people's government and interested institutions for practical purposes; and 3) disseminating knowledge related to industrial hygiene (occupational health).

Preparations to set up the Institute took most of the 1948. Until the Department of Medical Sciences was established within the Academy, the Institute made part of the Department of Natural Sciences. It brought into one place a number of institutions and departments that were related to industrial hygiene (occupational health) (5). The Academy's presidium appointed professor Branko Kesić director of the Institute, and he came into office on 15 February 1949. According to the Institute's statute, a Council was formed, consisting of three Academy representatives and one representative each of the Ministry of Public Health, Ministry of Labour, Ministry of Industry, and School of Medicine in Zagreb. At the first Council session held on 4 May 1949, academician Andrija Stampar was elected its chair, and he held this position until his death on 26 June 1958 (4).

At first the Institute had five units: Psychophysiology of Work; Work Pathology and Outpatient Clinic for Occupational Diseases; Biological Material Analysis; Industrial Toxicology; and Physical and Chemical Analysis of the Working Environment (5).

Ever since 1949 the Institute has regularly published its scientific quarterly Arhiv za higijenu rada (Archives of Industrial Hygiene), now Arhiv za higijenu rada i toksikologiju - Archives of Industrial Hygiene and Toxicology. Since 2008, the journal has been included in Science Citation Index Expanded.

Speaking of the Institute's activities, in 1996 the WHO issued a declaration based on adopted Global Strategy for Occupational Health for All: The Way to Health at Work (6). Its Objective 9. Strengthening of Research section stresses that scientific research 
is critical to the development of occupational health administration and planning, training and education, risk identification, assessment and practice. Every country should have a national research programme in occupational health adjusted to its specific needs. Most industrialised countries have delegated responsibility for such research to a national institute of occupational health or to a special department of occupational health in a university. Thanks to Štampar's visionary foresight, Croatia, which in 1948 was only at the beginning of industrial development, established an institute whose purpose and activities anticipated what the WHO would propose as national requirements nearly 50 years later!

The Institute soon grew when the Academy decided to join new units and laboratories, expanding its scope to medical research, which is why the Institute changed name to Institute for Medical Research (IMR). In a 1958 reform, the Institute became independent of the Academy, and lost some of its units, returning to the original scope of activities related to industrial hygiene/occupational health and some environmental health and basic research programmes. This led to another change of name to today's Institute for Medical Research and Occupational Health.

Now, looking 60 years back, I believe that the Institute has done justice to Štampar's idea about a research institution that would meet the nation's needs in occupational health. I also believe that Štampar himself would have been pleased with what has been achieved ever since, even at the international level. Not that this was a path strewn with roses, but we hope that the days of misunderstanding and hindrances are now behind us. The perspectives are encouraging, and the Institute will continue to successfully carry out its original tasks.

\section{REFERENCES}

1. Grmek MD. Medicinska enciklopedija [Medical Encyclopaedia, in Croatian]. Volume 6. Zagreb: Jugoslavenski leksikografski zavod; 1970. pp. 193-4.

2. Stampar A. [Speech at the inaugural assembly of the Yugoslav Academy of Arts and Sciences held in Zagreb on 27-28 December 1947. Unpublished; archived with the Croatian Academy of Sciences and Arts, 1947. p. 17]

3. Jugoslavenska akademija znanosti i umjetnosti. Ljetopis Jugoslavenske akademije [Yearbook of the Yugoslav Academy, in Croatian]. Volume 56. Zagreb: Izdavački zavod Jugoslavenske akademije; 1952.

4. Kesić B. Institut za higijenu rada sada Institut za medicinska istraživanja 1948.-1958. [Institute of industrial hygiene, today's Institute for medical research and occupational health 1948 - 1958, in Croatian] Zagreb: Izdavački zavod Jugoslavenske akademije; 1959.

5. Štampar A. [Institute of Occupational Health: Activity report and programme for 1949. Unpublished; archived with the Croatian Academy of Sciences and Arts in Zagreb; 1948. pp. 1-3.]

6. World Health Organization (WHO). Global strategy on occupational health for all: the way to health at work. Geneva: World Health Organization; 1995. 
Sažetak

\section{ANDRIJA ŠTAMPAR I INSTITUT ZA HIGIJENU (MEDICINU) RADA, SADA INSTITUT ZA MEDICINSKA ISTRAŽIVANJA I MEDICINU RADA}

U uvodu se ističe da su se u 2008. godini preklopile dvije važne, međusobno povezane, obljetnice. Prije 120 godina rođen je Andrija Štampar. Te je godine ujedno i 50. godišnjica njegove smrti. U 2008. navršilo se 60 godina djelovanja Instituta za higijenu rada (sada Institut za medicinska istraživanja i medicinu rada), koji je na prijedlog tadašnjeg predsjednika JAZU Andrije Štampara osnovan zaključkom Skupštine Akademije održane 27. prosinca 1947.

U prvom dijelu teksta sažet je Štamparov bogat životni put: od rođenja 1. rujna 1888. u Drenovcu kod Slavonskog Broda, gimnazijskih dana u Vinkovcima, studija medicine u Beču. Već kao studenta medicine Štampara su zanimali problemi zdravstvenog prosvjećivanja naroda, zalagao se za socijalizaciju medicine i unapređenje javnog zdravstva. Idealima koje je formulirao u studentskim danima Štampar je ostao vjeran tijekom čitavoga kasnijeg života. Nakon što je radio jedno vrijeme kao liječnik (Karlovac, Nova Gradiška) te bio mobiliziran u vrijeme I. svjetskog rata, nakon završetka rata slijedi značajan dio njegove aktivnosti na funkciji načelnika Higijenskog odjela u Ministarstvu narodnog zdravlja novostvorene države. Slijedom svojeg ideološkog programa koji je definirao, Štampar je utemeljio zdravstvenu službu u ondašnjoj Jugoslaviji, pokrenuo je i omogućio izgradnju brojnih javnozdravstvenih i higijenskih ustanova, pripremio donošenje potrebnih zakonskih propisa i omogućio usavršavanje i specijalizacije velikom broju liječnika u različitim medicinskim disciplinama. Uvođenjem šestojanuraske diktature kralja Aleksandra bio je prekinut Štamparov rad u Ministarstvu narodnog zdravlja. U svibnju 1931. Štampar je umirovljen.

Slijedi vrlo važno razdoblje Štamparove aktivnosti kao eksperta u zdravstvenoj organizaciji Društva naroda, $\mathrm{s}$ višegodišnjim djelovanjem izvan naše zemlje. U tom se dijelu posebno izdvajaju njegovi boravci u Kini gdje je pomagao kineskim vlastima u organizaciji i izgrađivanju javne zdravstvene službe.

U proljeće 1939. nakon povratka u zemlju, potvrđen je Štamparov izbor za profesora higijene i socijalne medicine na Medicinskom fakultetu u Zagrebu (iniciran još 1931.). Njegove aktivnosti, u to vrijeme usmjerene na unapređenje medicinske nastave, prekinuo je II. svjetski rat. Štampara je uhitila njemačka policija i odveden je u Graz gdje je najprije u zatvoru, a zatim u internaciji proveo sve vrijeme do kraja rata.

U svibnju 1945. vraća se u Zagreb i ponovno preuzima dužnost profesora higijene i socijalne medicine te funkciju direktora Škole narodnog zdravlja. U školskoj godini 1945/46. Štampar je bio rektor Sveučilišta u Zagrebu, a u više je navrata biran i za dekana Medicinskog fakulteta. Prilikom poslijeratne obnove rada Jugoslavenske akademije znanosti i umjetnosti i njezine reorganizacije postao je njezinim pravim članom i predsjednikom 1947. godine. U okvirima Štamparove aktivnosti u tim godinama nakon II. svjetskog rata važno mjesto zauzima njegov rad na polju međunarodne zdravstvene suradnje. Na Konferenciji Ujedinjenih naroda u Londonu 1946. Štampar je izabran za prvog potpredsjednika Ekonomskog i socijalnog vijeća te člana Pripremnog komiteta za stvaranje Svjetske zdravstvene organizacije (SZO). U New Yorku je 1946. izabran za predsjednika Interimne komisije koja je obavljala funkciju SZO sve do ratifikacije njezina ustava 7. travnja 1948. Predsjedavao je Prvoj svjetskoj zdravstvenoj skupštini održanoj u Ženevi u lipnju 1948. U svibnju 1955, na osmom zasjedanju Skupštine SZO, održanom u Meksiku, dodijeljena mu je medalja i nagrada zaklade Léona Bernarda, što je najveće međunarodno priznanje za zasluge na polju socijalne medicine (javnog zdravstva).

U osvrtu na odnos Štampara prema znanosti te na pitanje što je Štampara motiviralo da inicira stvaranje Instituta za higijenu (medicinu) rada, citira se nekoliko odabranih odlomaka iz govora što ga je Štampar kao predsjednik održao 28. 12. 1947. na svečanoj Škupštini Akademije. Između ostaloga Štampar je tom prilikom istakao da je položaj znanosti u današnjem društvu drukčiji nego što je bio prije, osobito u 19. stoljeću, kad je znanost bila individualna i razvijala se bez plana, a često u službi privatnih interesa. Danas znanost preuzima na sebe važne društvene funkcije i služi potrebama čovjeka i ljudske zajednice. Potrebe čovjeka su glavni motiv za znanstvena istraživanja, jer znanost može pružiti znanje potrebno pri zadovoljavanju ovih potreba. "I rad je jedna od glavnih ljudskih potreba. Ali rad mora za radnika predstavljati radost, a ne ropstvo. Znanost može pomoći da radnik bude gospodar mašine, a ne mašina njegov (gospodar).”

U povodou odluke o osnivanju Instituta za higijenu (medicinu) rada, Štampar ističe da će se taj Institut baviti fiziologijom i patologijom rada. Njegovo djelovanje past će baš u vrijeme kad se brzim tempom provodi industrijalizacija zemlje, koja iziskuje i rješavanje mnogih industrijsko-higijenskih pitanja.

Kad je riječ o potrebi osnivanja Instituta za higijenu (medicinu) rada, Štampar je istaknuo kako "moramo biti 
svjesni da zaštita radničkog zdravlja nije samo pitanje humanosti već je uvjet za izgradnju i uspješan razvoj naše (socijalističke) privrede". Pitanja zaštite radničkog zdravlja mogu se, kako je Štampar naglašavao, uspješno rješavati samo ako se obrađuju znanstveno.

Tijekom 1948. izvršeni su pripremni radovi na osnivanju Instituta. Do osnivanja IV. odjela - Razreda za medicinske znanosti, Institut je djelovao u sastavu III. odjela (razreda) za prirodne i medicinske znanosti. Formiran je od niza ustanova i jedinica koje su se bavile pitanjima higijene (medicine) rada. Zaključkom predsjedništva JAZU za direktora Instituta postavljen je prof. dr. Branko Kesić, koji je 15. veljače 1949. preuzeo vodstvo Instituta. Prema odredbama Pravilnika o radu Instituta, formiran je Savjet Instituta. Na prvoj sjednici Savjeta koja je održana 4. svibnja 1949. za predsjednika je izabran akademik Andrija Štampar, koji je tu dužnost obavljao sve do svoje smrti 26. lipnja 1958.

Institut je započeo svoje djelovanje u pet radnih jedinica: Psihologija i fiziologija rada, Patologija i klinika rada s dispanzerom za profesionalne bolesti, Pretrage biološkog materijala, Industrijska toksikologija, Fizička i kemijska ispitivanja radne okoline.

Od godine 1949. u Institutu se objavljuje Arhiv za higijenu rada, kasnije Arhiv za higijenu rada i toksikologiju, koji redovito izlazi s četiri broja na godinu, a 2008. godinu zaključuje svojim 59. volumenom. Od tog volumena Arhiv je uz ostale indeksne baze uvršten u Science Citation Index Expanded.

Kad je riječ o osnivanju i zadacima Instituta za higijenu (medicinu) rada, navodi se da je 1996. godine SZO donijela Deklaraciju o zdravlju na radu za sve. Uz Deklaraciju prihvaćena je i Globalna strategija za zdravlje na radu za sve - kako do zdravlja na radu. Dio dokumenata o globalnoj strategiji za zdravlje na radu odnosi se na znanstvena istraživanja (Objective 9. Strengthening of Research). Ističe se da su ona bitna za razvoj organizacije medicine rada, planiranje, edukaciju i usavršavanje, identificiranje rizika i praktične aktivnosti. Svaka zemlja s obzirom na svoje specifičnosti mora imati svoj nacionalni program istraživanja u medicini rada. Najveći broj industrijski razvijenih zemalja povjerio je ulogu i zadatke u takvim istraživanjima nacionalnim institutima medicine rada ili to obavljaju posebne jedinice (odjeli) medicine rada pri sveučilištima. U nas kao zemlji koja je 1948. bila tek na početku svojeg industrijskog razvoja stvoren je, zahvaljujući dalekovidnosti A. Štampara, znanstveni institut čiji su svrha i zadaci bili sukladni onomu što SZO 1996. godine, gotovo pedeset godina kasnije, predlaže i traži kao potrebu svake zemlje.

U okviru zadataka koji su bili zadani odvijala se aktivnost Instituta. Zaključkom JAZU bile su u međuvremenu Institutu pripojene neke manje Akademijine jedinice i laboratoriji koji su se bavili istraživačkim radom na području medicine pa je s tim u vezi Institut promijenio ime u Institut za medicinska istraživanja (IMI). Godine 1958. slijedom promjene u zakonskim propisima Institut je postao samostalna znanstvena ustanova. Neke od pripojenih jedinica su tada ponovno izdvojene iz Instituta. Preostalo je ono što se odnosilo na prvobitni sadržaj, t. j. higijenu i medicinu rada s time da su uključeni i programi s područja zdravstvene ekologije te neki drugi više temeljno orijentirani, pa je dobio ime koje i sada nosi: Institut za medicinska istraživanja i medicinu rada.

Na koncu je izraženo mišljenje da se prilikom obilježavanja 60 godina djelovanja Instituta može smatrati da su s uspjehom realizirane Štamparove zamisli o potrebi jedne takve istraživačke ustanove te da se može reći da bi Štampar bio zadovoljan onime što je u međuvremenu postignuto u smislu potrebe i afirmacije takve ustanove u nas pa i u međunarodnim razmjerima. Perspektive su otvorene da bi IMI i dalje s uspjehom mogao izvršavati zadatke koji su mu bili namijenjeni prilikom osnivanja.

\section{CORRESPONDING AUTHOR:}

Marko Šarić, academician

Institute for Medical Research and Occupational Health

Ksaverska c. 2

10000 Zagreb, Croatia

E-mail:marko@imi.hr 